\title{
How CETYS Engineering is Preparing Its Students for Success
}

\author{
Ana Melissa Algravez ${ }^{1}$, Dan L. Shunk ${ }^{1}$, Jorge Sosa Lopez ${ }^{1}$, Juan M. Terrazas Gaynor ${ }^{1}$ \& Juan R. Silva ${ }^{1}$ \\ ${ }^{1}$ College of Engineering, CETYS University, Mexico \\ Correspondence: Ana Melissa Algravez, Assistant of the College of Engineering, CETYS University, Mexico
}

Received: June 22, 2020

Accepted: October 27, 2020

Online Published: November 10, 2020

doi:10.5430/ijhe.v10n1273

URL: https://doi.org/10.5430/ijhe.v10n1p273

\begin{abstract} formed that spring. At the May 2017 meeting of the EAC it asked:

"What competencies are needed for the engineer of tomorrow?"

"How is CETYS preparing its engineering students to meet this challenge?"
\end{abstract}

The Centro de Enseñanza Técnica y Superior (CETYS University) is a private institution established in 1961 in Baja California, Mexico under the auspices of a group of visionary entrepreneurs committed to education. CETYS Engineering recognized in the spring of 2016 that it needed a formal organization to provide third-party, external feedback for the advancement of the CETYS College of Engineering. An Engineering Advisory Council (EAC) was

These two simple questions lead to a year-long study conducted by the CETYS College of Engineering. With a broad industry survey resulting in a sample size of 42 subject matter experts (SME's) we determined what are the most important Domains of Attributes, Skills and Abilities an engineer needs.

Using this domain prioritization, we then learned "What are the biggest competency gaps?" that industry is finding in entry-level engineers today from all universities.

Using this gap analysis, we then looked at the CETYS curriculum and determined that almost all of the gaps are overtly addressed in multiple classes.

Finally, the survey led the CETYS College of Engineering to take action on how address those gaps.

Keywords: engineering competency, domains knowledge, competency structured analysis tool

\section{Introduction}

CETYS Engineering understands its responsibility to provide the best talent possible to the private and public sectors of Baja and beyond. Universities do this in two fundamental ways:

1. By educating those who will define the future.

2. By generating the ideas and discoveries that can transform the present and build a better world.

But to do this mission effectively, we need to understand the competencies required by the student in the dynamic world of ours. Competency-based education is a modern trend based upon the premise that students must be able to demonstrate mastery of key concepts, attributes, skills and abilities. This is not a time-based educational platform as has been present in the past $\sim$ e.g. "take 140 credit hours, average a "C" or better and you will graduate!" The U.S. Department of Education proclaims "competency-based learning leads to better student outcomes because the pace of learning is customized to each student."

\subsection{Thinking with the End in Mind}

In order to capture what industry sought, a detailed Engineering Competency-based Strategic Assessment Tool (CompSAT) questionnaire was developed by the study team at CETYS. We anticipated that the questionnaire results would serve many valuable roles:

1. Use the survey to drive "industry-prepared" CETYS graduates.

2. Use the survey to help CETYS hiring of new faculty.

3. Use the survey to support the Baja development of research clusters.

4. Use the various competency priorities to create degrees that are truly needs driven. 
5. Use the survey to demonstrate the industry involvement in academic program creation in support of future accreditation efforts.

The questionnaire targeted the following fundamental question. Looking out $3-5$ years:

"For an entry level engineer in your industry sector, he or she should have the following competencies upon graduation from CETYS"

(In this case we define competencies as domain-specific knowledge that pertains to a specific industry sector.)

By competencies we mean domain-specific knowledge that pertains to that industry. For example, under the competency of "DESIGN"

- An entry level engineer entering the aerospace sector may need to know Design Thinking, requirements capture, product / process definition, Design - Manufacturing integration, mCAD, etc.

- An entry level engineer entering the maquiladora sector may need different competencies. He or she may need to know Design - Manufacturing integration but may only need to know Drafting rather than mCAD.

\subsection{The Instrument Theoretical Foundation}

The plan to develop this assessment began with a literature review. The literature taxonomy easily clustered into three categories:

1. What is the impact of competency-based learning?

2. What is the impact of a competent workforce in industry?

3. What assessment tools have been successful in developing answers?

We address each of these briefly.

Competency-based learning has existed for many years. The U.S. Department of Education (DOE) states "competencybased learning leads to better student outcomes because the pace of learning is customized to each student." The National Academy of Sciences emphasizes that the "engineer of tomorrow will be educated at institutions that can provide customized, tailored, and tuned education to the learner."

Industry has been pushing competency-based learning because they need critical thinkers. But as the Wall Street Journal points out in 2017(Wall Street Journal, 2017), many colleges are failing to improve the critical thinking skills. "The challenge of working on complex problems will require systems designers with skills in basic science and math, multicultural and multidiscipline teamwork and a solid grounding in the humanities, social sciences and economics" was articulated by the National Academy of Sciences in 2004. Dano points out (Dano, E.B., 2019) that "corporate success mandates that a well-trained, experienced and competent workforce be employed." The Organization for Economic Co-operation and Development (OECD) published two reports highlighting the educational needs in Mexico:

- In 2015 the OECD states that in Mexico “to unleash the country's potential requires a comprehensive programme to improve the skills"

- In 2016 the OECD reinforced their comments by quantifying the skills gap in Mexico at $45 \%$ of the total workforce. This compares to $40 \%$ in the United States and 25\% in China.

Finally, the Institution of Engineering and Technology (IET) in the United Kingdom Skills Survey of 2019 showed that:

- $60 \%$ of companies responding said recruitment of engineering and technical staff with the right skills is the biggest barrier to achieve business objectives

- Yet only 20\% expect the supply of engineering skills coming into industry will improve.

As far back as 1999 have assessment methodologies been studied by Lang, et al.( Lang, James D, Susan Cruse, Francis D. McVey \& John McMasters, 1999). Lang states that "quantitative methodologies such as formal surveys and structured interviews can be used to capture industry expectations of the needed attributes." Serna and her team in 2018 [14] found that many assessment methods exist. Their focus was on student inputs and impacts. The CETYS study complements this by using industry inputs and impacts. Finally, there was one caution that the CETYS team took seriously. Cruz, et al. (Cruz, Mariana Leandro, Gillian N. Saunders-Smits \& Pim Groen, 2019) in 2019 point out that they "found $63 \%$ of the curriculum surveys used questionnaires." But they highlight that "questionnaires alone are 
not a good practice and should be used in combination with other methods" to validate the results. As you will find later CETY did just this by reviewing all the findings with the EAC in a formal review.

The CETYS Engineering Advisory Committee (EAC) study team developed a knowledge base of dozens of competency assessment instruments based upon the literature. What evolved was a composite of many of these. We call this composite instrument the CompSAT (Competency-based Strategic Assessment Tool). The underlying theory behind the CompSAT has been used in various forms for over a decade throughout North America to identify the gaps for a particular topical area. For example, we use the same format and gap analysis to assess the strategic process gaps in industry, the leadership gaps in industry, the next generation of manufacturing called "Industry 4.0" preparedness, the supply chain gaps, etc. Each of these instruments develops a customized list of questions to be asked of subject matter experts (SME). For each question we ask the "SME" to provide three (3) values:

- Where are you Currently (C) - on a scale of 1 to 5 what is the current value assigned to this question. A " 1 " represents a very basic knowledge of the topic while a " 5 " represents an ability to synthesize and evaluate from a deep understanding. The rubric is a modified Bloom scale.

- What is your Desired state (D)- again using the rubric of 1 to 5 what should this response be in three to five years? This rather long-range horizon was necessary because for the academic supply chain to effectively address any gaps, it will take some time to change the curriculum followed by a longer time to matriculate the students.

- If there is a Gap between the Current and the Desired, what would be the Importance ( I) to fill the gap? - again using a rubric of 0 to 5 what is the value to the customer and the company if the gap between the Current and the Desired is closed? A value of 0 says there is no importance, a value of 1 would represent a very low value of importance while a 5 would represent such an important value that this could lead to a competitive advantage.

We then capture all the inputs and do a very simple calculation:

\section{CompSAT Value $=($ Desired - Current $) *$ Importance}

Since this survey was targeting the engineering competencies needed by industry in Baja, Mexico we limited our focus to only the STEM professionals. (Science, Technology, Engineering and Math) professionals using the current vernacular.

\subsection{Conducting the Survey}

After we have identified our subject matter experts (SME's) we send them the questionnaire. We used Survey Monkey as the data capture method.

In Section 1 we asked the respondent to identify themselves. This series of questions included their industry segment which we used later to stratify the results.

In Section 2 of the questionnaire we ask the SME to review all of the technical competencies we have identified. The questions for each technical domain competency addressed: is this technical domain needed by your sector $\sim$ and if so, how IMPORTANT is this STEM domain to your sector's success? If the "SME" thinks this is important enough to give the Domain a 3, 4 or 5 then we asked them to continue by expanding the Domain into the various Competencies.

In Section 3 of the questionnaire we ask the "SME" to review the ability of your STEM professionals to problem solve and think critically. Most of the SME's at companies have highlighted these skills as mandatory for a successful STEM professional.

In Section 4 of the questionnaire we ask that the SME review all of the academic skills STEM professionals will need as well. Here a similar two-part series of questions will be asked.

In Section 5 of the questionnaire we ask that the SME review all of the personal and workplace competencies a STEM professional may need.

In the questionnaire we ask the following: For each Domain: we are seeking the IMPORTANCE of this body of knowledge in your industry sector in THREE (3) TO FIVE (5) YEARS. The scale we ask you use is as follows:

0 . No importance to our sector at all.

1. A very LOW importance. This set of competencies contribute VERY LITTLE to your sector success.

2. A LOW importance. 
3. A MEDIUM importance.

4. A HIGH importance.

5. A VERY HIGH importance. This set of competencies drive the competitive advantage of your sector success.

IF the "SME" gave the Domain an Importance value of 3, 4, or 5, we asked them to dig deeper. For those Domains of importance $(3,4$, or 5$)$ we then asked which Competencies that make-up the domain are of the highest importance and where are the competency GAPS that we must fill.

For each Competency: again, we use the modified Bloom scale for measuring the Current state of the engineering hire and the "Desired future state" looking out $3-5$ years of the desired engineering hire. The scale used is the following for both the Current and the Desired ("APEGBC Competency Assessment Guide" used as a starting point for the creation of the scale):

0. Little or no exposure to the competency

1. Training Level: general appreciation and awareness

2. Basic knowledge and understanding of objectives

3. Approaching a professional level, conducts tasks of moderate complexity

4. Works at a professional level, conducts responsible and varied activities

5. At a mature professional level, independently coordinates the tasks.

An example of the detailed competency assessment questions is found below for Sections 2, 3, 4 and 5. A complete competency questionnaire can be provided upon request. 


\begin{tabular}{|l|l|l|l|l|}
\hline Domain & Competencies & $\begin{array}{l}\text { Current } \\
\mathbf{( 1 - 5 )}\end{array}$ & $\begin{array}{l}\text { Desired } \\
\mathbf{( 1 - 5 )}\end{array}$ & $\begin{array}{l}\text { Importance } \\
\mathbf{( 0 - 5 )}\end{array}$ \\
\hline 2.1 Program Planning & & & & \\
\hline & Project management principles & & & \\
\hline & Project planning, estimating & & & \\
\hline & Project management & & & \\
\hline & $\begin{array}{l}\text { Project costing, benefits and financial } \\
\text { impacts }\end{array}$ & & & \\
\hline & Project scheduling & & & \\
\hline
\end{tabular}

\begin{tabular}{|c|c|c|c|c|}
\hline Domain & Competencies & $\begin{array}{l}\text { Current } \\
(1-5)\end{array}$ & $\begin{array}{l}\text { Desired } \\
(1-5)\end{array}$ & $\begin{array}{l}\text { Importance } \\
(0-5)\end{array}$ \\
\hline \multicolumn{5}{|l|}{$\begin{array}{l}3.1 \text { Identify the } \\
\text { Problem }\end{array}$} \\
\hline & $\begin{array}{l}\text { Capture requirements (minimum } \\
\text { essential functionality, nice to have) }\end{array}$ & & & \\
\hline & $\begin{array}{l}\text { Describe issues preventing system / } \\
\text { product platform from meeting } \\
\text { requirements }\end{array}$ & & & \\
\hline & $\begin{array}{l}\text { Determine direct and indirect impact } \\
\text { of each issue on form / fit / function }\end{array}$ & & & \\
\hline & Identify root cause of issues & & & \\
\hline
\end{tabular}

\begin{tabular}{|l|l|l|l|l|}
\hline Domain & Competencies & $\begin{array}{l}\text { Current } \\
\mathbf{( 1 - 5 )}\end{array}$ & $\begin{array}{l}\text { Desired } \\
\mathbf{( 1 - 5 )}\end{array}$ & $\begin{array}{l}\text { Importance } \\
\mathbf{( 0 - 5 )}\end{array}$ \\
\hline 4.1 Read & $\begin{array}{l}\text { Able to locate understand and } \\
\text { interpret written technical and non- } \\
\text { technical information }\end{array}$ & & \\
\hline & Able to identify relevant details & & \\
\hline & $\begin{array}{l}\text { Infer or locate meaning of unknown } \\
\text { or technical vocabulary }\end{array}$ & & \\
\hline
\end{tabular}




\begin{tabular}{|l|l|l|l|l|}
\hline Domain & Competencies & $\begin{array}{l}\text { Current } \\
(\mathbf{1}-\mathbf{5})\end{array}$ & $\begin{array}{l}\text { Desired } \\
(\mathbf{1}-\mathbf{5})\end{array}$ & $\begin{array}{l}\text { Importance } \\
\mathbf{( 0 - 5 )}\end{array}$ \\
\hline $\begin{array}{l}5.1 \text { Interpersonal Skills } \\
(\mathrm{g})\end{array}$ & & & & \\
\hline & $\begin{array}{l}\text { Interact appropriately and } \\
\text { respectfully }\end{array}$ & & & \\
\hline & Work effectively with people & & & \\
\hline & Be flexible and open minded & & & \\
\hline & Listen to and consider other's views & & & \\
\hline
\end{tabular}

\section{The Findings}

\subsection{Survey Participants by Industry Sector}

Survey responses came from 42 subject matter experts (SME's) in a variety of industry domains in Baja, Mexico. The breakdown of these respondents is as follows:

\begin{tabular}{|c|l|}
\hline Industry Sector & Respondents \\
\hline$\bullet \quad$ Aerospace & 19 \\
\hline$\bullet \quad$ Automotive & 3 \\
\hline$\bullet \quad$ Glass & 5 \\
\hline$\bullet \quad$ Consulting & 9 \\
\hline$\bullet \quad$ Electronic & 3 \\
\hline$\bullet \quad$ Medical Total & 3 \\
\hline
\end{tabular}

\subsection{Findings and Assessments}

The response shown has $45 \%$ coming from aerospace. The reason is that this sector is actively involved in the competency definition and gaps. Although heavily skewed toward the Aerospace sector, the Subject Matter Experts (SME's) are known by the university personnel and are qualified in many of the sectors listed. Using the data collected we shall proceed to answer six questions with the data below:

- What Domains of competency are found to be the most important for an entry level engineer?

- What are the single biggest gap(s) in competency for each of the prioritized Domains?

- What is the prioritized list of largest competency gaps?

- How does this prioritized list of Domains compare to TUEE?

- "TUEE" is the American Society for Engineering Education "Transforming Undergraduate Education in Engineering" series of workshops.

- What competencies are needed for the engineer of tomorrow?

- How is CETYS preparing its engineering students to meet this challenge? 


\subsubsection{Most Important Domains}

These are the prioritized Domains ranked by their "I" Importance score. We used this finding to be the overarching focus for the survey. These industry sector Important Domains must drive our planning for the future.

Table 1. Most Important Domains

\begin{tabular}{|c|c|c|c|}
\hline$\overline{\text { Rank }}$ & Domain & Average "I" Score & Domain Name \\
\hline$\overline{1}$ & 5.3 & 4.85 & Ethical Responsibility \\
\hline 2 & 5.2 & 4.77 & Able to Function in a multi-disc team "d" \\
\hline 3 & 5.8 & 4.72 & Life Long Learning \\
\hline 4 & 4.3 & 4.70 & Communication - "g" \\
\hline 5 & 5.5 & 4.67 & Professionalism \\
\hline 6 & $2.12+4.8$ & 4.56 & Problem Solving and Decision Making - "e" \\
\hline 7 & 4.7 & 4.56 & Teamwork \\
\hline 8 & 2.5 & 4.50 & Technical Content - Controls \\
\hline 9 & 4.5 & 4.50 & Critical and Analytical Thinking - "e" \\
\hline 10 & 5.7 & 4.46 & Dependability and Reliability \\
\hline 11 & 5.10 & 4.30 & Leadership \\
\hline 12 & 5.1 & 4.26 & Interpersonal Skills - "g" \\
\hline 13 & 5.6 & 4.23 & Initiative \\
\hline 14 & 3.4 & 4.23 & Communicate Problems and Solutions \\
\hline 15 & 4.2 & 4.17 & Writing Skills \\
\hline 16 & 2.22 & 4.17 & Project Management \\
\hline 17 & 5.9 & 4.16 & Ability to Work Remotely \\
\hline 18 & 3.1 & 4.13 & Identify the Problem \\
\hline 19 & 4.1 & 4.07 & Reading Skills \\
\hline 20 & 2.10 & 4.05 & Able to Apply Math and Science - "a" \\
\hline
\end{tabular}

$21 \quad 2.13 \quad 4.00 \quad$ Able to use skills and tools necessary for engineering practice - "k"

Please Note: letters in "' link the competency instrument to the ABET (Accreditation Board for Engineering and Technology, 2000) older criteria.

Domain Importance Assessment: With such broad technical knowledge requirements by different industry sectors, the specific industry Importance values focused more on overarching principles. The logical top priorities across all engineering disciplines are the ethical, teamwork, communication and professionalism domains. These are also found in all ABET and other accrediting body evaluation criteria for Schools of Engineering. We did a sector-by-sector analysis of Importance and concluded that the overarching principles of the "Whole Engineer" represented in Table 1 were reflective across sectors. 


\subsubsection{Singular Top Important Domain Competency Gaps}

These are the highest priority specific competency gap within a particular domain that were deemed Highly Important (scores of 3 or 4 or 5). These simply capture only one, highest gap.

Table 2. The Singular, Top Rated Gap within each of the Highest Priority Domains

\begin{tabular}{|c|c|c|c|c|}
\hline $\begin{array}{l}\text { Domain } \\
\text { Order }\end{array}$ & Rank & & $\begin{array}{l}\text { Domain } \\
\text { Importance }\end{array}$ & Largest \\
\hline Rank & Competency & Competency Name & Average & Gap \\
\hline 11 & 5.10 & Leadership & 4.3 & 10.62 \\
\hline 4 & 4.3 & Communication - "g" & 4.7 & 8.31 \\
\hline 9 & 4.5 & Critical and Analytical Thinking - "e" & 4.5 & 8.19 \\
\hline 6 & $2.12+4.8$ & Problem Solving and Decision Making - "e" & 4.56 & 8.07 \\
\hline 18 & 3.1 & Identify the Problem & 4.13 & 7.92 \\
\hline 16 & 2.22 & Project Management & 4.17 & 7.71 \\
\hline 15 & 4.2 & Writing Skills & 4.17 & 7.08 \\
\hline 12 & 5.1 & Interpersonal Skills - "g" & 4.26 & 6.98 \\
\hline 17 & 5.9 & Ability to Work Remotely & 4.16 & 6.9 \\
\hline 7 & 4.7 & Teamwork & 4.56 & 6.84 \\
\hline 21 & 2.13 & $\begin{array}{l}\text { Able to use skills and tools necessary for } \\
\text { engineering practice - "k" }\end{array}$ & 4 & 6.8 \\
\hline 14 & 3.4 & Communicate Problems and Solutions & 4.23 & 6.72 \\
\hline 8 & 2.5 & Technical Content - Controls & 4.5 & 6.61 \\
\hline 20 & 2.10 & Able to Apply Math and Science - "a" & 4.05 & 6.56 \\
\hline 2 & 5.2 & Able to Function in a multi-disc team "d" & 4.77 & 6.53 \\
\hline 5 & 5.5 & Professionalism & 4.67 & 6.3 \\
\hline 19 & 4.1 & Reading Skills & 4.07 & 6.3 \\
\hline 13 & 5.6 & Initiative & 4.23 & 6.26 \\
\hline 10 & 5.7 & Dependability and Reliability & 4.46 & 5.66 \\
\hline 3 & 5.8 & Lifelong Learning & 4.72 & 5.14 \\
\hline 1 & 5.3 & Ethical Responsibility & 4.85 & 3.97 \\
\hline
\end{tabular}

Domain Singular Gap Assessment: Again, leadership and communication appear as the largest competency gaps within our highest important domains. But the emphasis on "Critical and Analytical Thinking - "e"', "Problem Solving and Decision Making - "e"" and "Identify the Problem" form the foundation of the technical skill set for every engineer. 


\subsubsection{Ranking the Biggest Competency Gaps}

These are the specific competency gaps within all the highest Importance I-score domains found above. This is an important, cross-cutting list comparing all the biggest gaps for all the Important Domains.

\begin{tabular}{lll}
\hline Competency & Title & Gap \\
\hline \hline 5.10.3 & Understand How to Make Change Happen & 10.62 \\
4.3 .5 & Able to Make a Presentation & 8.31 \\
4.5 .1 & Able to Capture True Requirements & 8.19 \\
4.3 .3 & Able to Speak and Present & 8.13 \\
2.12 .2 & Able to Formulate Alternative Solutions & 8.07 \\
3.1 .4 & Identify Root Cause of Issues & 7.92 \\
2.22 .5 & Problem Solving & 7.71 \\
2.12 .1 & Able to Capture Requirements & 7.34 \\
4.2 .2 & &
\end{tabular}

Table 3. Rank Ordering the Biggest Competency Gaps for All Important Domains

$\begin{array}{llc}\text { 4.2.3 } & \text { Able to Develop Ideas with Supporting Information and Examples } & 7.08 \\ 5.1 .4 & 6.98 \\ 5.9 .2 & \text { Listen to and Consider Other's Views } & 6.9 \\ 4.7 .2 & \text { Works Well Alone } & 6.84 \\ 2.13 .4 & \text { Able to participate as a member of a Problem Solving Team } & 6.8 \\ 3.4 .3 & \text { Able to Apply Probability and Statistics } & 6.72 \\ 2.22 .4 & \text { Obtain Approvals to Proceed } & 6.71 \\ 4.7 .1 & \text { Emotional Intelligence (EQ) } & 6.65 \\ 3.1 .2 & \text { Able to Contribute to a Team } & 6.64 \\ 2.5 .7 & \text { Able to Describe Issues Preventing System / Product Platform from } \\ 2.10 .5 & \text { meeting requirements } & 6.61 \\ 5.2 .1 & \text { Systems Integration } & 6.56\end{array}$

Biggest Competency Gap Assessment: The overall LARGEST GAP was "Understand How to Make Change Happen". This is a fundamental take-away from the Competency Assessment. We must infuse not only the analytical skill sets into our curriculum but add to this a deep understanding of how to make change happen in order for real, measurable accomplishments to be achieved.

2.2.4 Comparison of Domain Importance with TUEE Domain Importance

As introduced earlier TUEE (Transforming Undergraduate Education in Engineering) is a study conducted by the American Society of Engineering Education and the National Science Foundation. We compare the prioritized CETYS 
Engineering domain largest gaps with the prioritized TUEE largest gaps. Numbers for the TUEE equivalents are their rank order.

Table 4. Comparing the Survey Domain Importance Gaps from Table 1 and TUEE Equivalents

\begin{tabular}{|c|c|c|c|}
\hline Order & Domain & CETYS Domain Name & TUEE Equivalent \\
\hline 1 & 5.3 & Ethical Responsibility & 9. Ethics \\
\hline 2 & 5.2 & $\begin{array}{l}\text { Able to Function in a multi-disciplinary } \\
\text { team "d" }\end{array}$ & $\begin{array}{l}\text { 3. Formulate and Solve } \\
\text { 14. Teamwork }\end{array}$ \\
\hline 3 & 5.8 & Life Long Learning & 5. Continuous Learning \\
\hline 4 & 4.3 & Communication - "g" & 1. Communication Skills \\
\hline 5 & 5.5 & Professionalism & \\
\hline 6 & $2.12+4.8$ & Problem Solving and Decision Making & $\begin{array}{l}\text { 3. Formulate and Solve } \\
\text { 11. Calculated } \\
\text { 12. Prioritization }\end{array}$ \\
\hline 7 & 4.7 & Teamwork & 14. Teamwork \\
\hline 8 & 2.5 & Technical Content - Controls & \\
\hline 9 & 4.5 & Critical and Analytical Thinking - "e" & 10. Critical Thinking \\
\hline 10 & 5.7 & Dependability and Reliability & \\
\hline 11 & 5.10 & Leadership & \\
\hline 12 & 5.1 & Interpersonal Skills - "g" & 1. Communication \\
\hline 13 & 5.6 & Initiative & 6. Motivation \\
\hline 14 & 3.4 & Communicate Problems and Solutions & 1. Communication \\
\hline 15 & 4.2 & Write & 1. Communication \\
\hline 16 & 2.22 & Project Management & 13. Project Management \\
\hline 17 & 5.9 & Ability to Work Remotely & \\
\hline 18 & 3.1 & Identify the Problem & 3. Formulate and Solve \\
\hline 19 & 4.1 & Read & 1. Communicate \\
\hline 20 & 2.10 & Able to Apply Math and Science - "a" & 2. Science Fundamentals \\
\hline 21 & 2.13 & $\begin{array}{l}\text { Able to use skills and tools necessary for } \\
\text { engineering practice - "k" }\end{array}$ & 2. Science Fundamentals \\
\hline
\end{tabular}

Comparison of Survey Domain Rank Order of Importance to TUEE Assessment: The National Science Foundation of the USA commissioned a study called TUEE - "Transforming Undergraduate Education in Engineering". This report had three phases. In the first phase they looked at competency gaps. In order to achieve closure, the EAC study team compared the largest Domain gaps with those found by TUEE.

\subsubsection{Comparison of Competency Gaps with CETYS Engineering Coverage}

In order to complete the assignment given by the EAC, the study team compared the prioritized gaps with how CETYS is addressing each of the gaps 
Table 5. Prioritized Competency Gaps from Table 3 vs. Courses in Engineering at CETYS

\begin{tabular}{|c|c|c|c|}
\hline Competency & Title & Gap & Current CETYS Courses by Course Number \\
\hline 5.10 .3 & $\begin{array}{l}\text { Understand How to Make } \\
\text { Change Happen }\end{array}$ & 10.62 & NOT SPECIFICALLY ADDRESSED \\
\hline 4.3 .5 & $\begin{array}{l}\text { Able to Make a } \\
\text { Presentation }\end{array}$ & 8.31 & $\begin{array}{l}\text { FCG COURSES: HCS001, HHU001, HCS002, HHU002, } \\
\text { HHU003, } \\
\text { HCS100, HCS101, HCS102, HCS103 }\end{array}$ \\
\hline 4.5.1 & $\begin{array}{l}\text { Able to Capture True } \\
\text { Requirements }\end{array}$ & 8.19 & FCE COURSES: IND101, IND109, IND111, NAE108, IND112 \\
\hline 4.3 .3 & Able to Speak and Present & 8.13 & $\begin{array}{l}\text { FCG COURSES: HCS001, HHU001, HCS002, HHU002, } \\
\text { HHU003, } \\
\text { HCS100, HCS101, HCS102, HCS103 }\end{array}$ \\
\hline 2.12 .2 & $\begin{array}{l}\text { Able to Formulate } \\
\text { Alternative Solutions }\end{array}$ & 8.07 & FCE COURSES: IND101, IND109, IND111, NAE108, IND112 \\
\hline 3.1 .4 & $\begin{array}{l}\text { Identify Root Cause of } \\
\text { Issues }\end{array}$ & 7.92 & FCE COURSES: IND101, IND109, IND111, NAE108, IND112 \\
\hline 2.22 .5 & Problem Solving & 7.71 & FCE COURSES: IND101, IND109, IND111, NAE108, IND112 \\
\hline 2.12 .1 & $\begin{array}{l}\text { Able to Capture } \\
\text { Requirements }\end{array}$ & 7.34 & FCE COURSES: IND101, IND109, IND111, NAE108, IND112 \\
\hline 4.2 .2 & $\begin{array}{l}\text { Able to Communicate } \\
\text { Thoughts and Ideas Using } \\
\text { Written Information }\end{array}$ & 7.08 & $\begin{array}{l}\text { FCG COURSES: HCS001, HHU001, HCS002, HHU002, } \\
\text { HHU003, } \\
\text { HCS } 100, \text { HCS } 101, \text { HCS } 102, \text { HCS } 103\end{array}$ \\
\hline 4.2 .3 & $\begin{array}{lr}\text { Able to Develop } & \text { Ideas } \\
\text { with } & \text { Supporting } \\
\text { Information } & \text { and } \\
\text { Examples } & \end{array}$ & 7.08 & FCE COURSES: IND101, IND109, IND111, NAE108, IND112 \\
\hline 5.1 .4 & $\begin{array}{l}\text { Listen To and Consider } \\
\text { Other's Views }\end{array}$ & 6.98 & $\begin{array}{l}\text { FCG COURSES: HCS001, HHU001, HCS002, HHU002, } \\
\text { HHU003, }\end{array}$ \\
\hline 2.22 .4 & $\begin{array}{l}\text { Emotional Intelligence } \\
\text { (EQ) }\end{array}$ & 6.71 & NOT SPECIFICALLY MAPPED TO A COURSE \\
\hline 4.7.1 & $\begin{array}{l}\text { Able to Contribute to a } \\
\text { Team }\end{array}$ & 6.65 & FCE COURSES: IND101, IND109, IND111, NAE108, IND112 \\
\hline 3.1 .2 & $\begin{array}{l}\text { Able to Describe Issues } \\
\text { Preventing System / } \\
\text { Product Platform from } \\
\text { meeting requirements }\end{array}$ & 6.64 & FCE COURSES: IND101, IND109, IND111, NAE108, IND112 \\
\hline 2.5 .7 & Systems Integration & 6.61 & FCE COURSES: IND101, IND109, IND111, NAE108, IND112 \\
\hline 2.10 .5 & Able to Apply Statistics & 6.56 & $\begin{array}{l}\text { FCP COURSES: IMA101, IND104, IND107, IND108 } \\
\text { FCE COURSES: IND101, IND109, IND111, NAE108, IND112 }\end{array}$ \\
\hline 5.2 .1 & $\begin{array}{l}\text { Able to Contribute to a } \\
\text { Team }\end{array}$ & 6.53 & FCE COURSES: IND101, IND109, IND111, NAE108, IND112 \\
\hline
\end{tabular}

Survey Competency Gaps compared to CETYS Coverage Assessment:

The results shown in Table 5 reinforce the coverage found in the CETYS Engineering curriculum. To get to the answer of these two EAC questions took a thorough analysis of Domain Importance and Competency Gaps found by our 
SME's. The conclusion is that CETYS Engineering can find multiple courses covering all of the highest priority Competency gaps except for three. These three are listed below with the CETYS actions to address.

1. Understand How to Make Change Happen - to incorporate how to make change happen into the curriculum is being addressed by introducing this topic and discussion in many of our classes. We have introduced in our undergraduate classes a complete lecture on this topic. But to validate if the student has mastered this is very difficult in an academic setting.

2. Works Well Alone - this study was conducted before the Corona Virus COVID 19 struck. Since classes were transformed to a remote learning format, we have established a living laboratory of CETYS students working alone. Feedback from the students has been mixed many are flourishing in a "study at home" environment but several find the need for time management required when their cohort attends classes together. This experiment will continue into the Fall of 2020 with meaningful modifications. Feedback from the faculty was initially to push back "students cannot learn the material from home". But this mindset has changed dramatically as the real need for remote learning materialized. Faculty of engineering embraced the change and made the transition to remote learning in a seamless manner. Currently CETYS is formalizing its plans on the role of remote learning in the total educational ecosystem.

3. Emotional Intelligence (EQ) - just like the comments on Making Change Happen above, we are preparing our students to successfully work in teams, deliver to timelines and be able to support interpersonal relationships in a proper manner. The outcomes of the team projects, interactions with industry on internships and external assessments demonstrate that our students are emotionally sensitive and stable, for the most part.

\section{The Overall Assessment}

The CETYS Engineering Advisory Committee ask of the engineering program two questions:

"What competencies are needed for the engineer of tomorrow?"

"How is CETYS preparing its engineering students to meet this challenge?"

These required a very detailed look at the competencies needed and how CETYS is meeting those needs. A rigorous assessment using a CompSAT instrument that allowed 42 SMEs in Baja, Mexico to contribute lead to findings of great value. Summarizing some of these findings:

- It is no surprise that Ethical Responsibility, Domain 5.3, is the most important domain expected of an engineer.

- What is encouraging is that industry rates Ethics as Very Important but they are finding that engineering graduates have mastered this competency.

- What industry is telling us is that there are clusters of gaps found in engineers today:

- Understand how to make change happen

- Able to capture true requirements

- Able to speak and present

- Able to formulate alternative solutions

- Able to identify root cause of issues

- Problem solving

- Able to capture requirements,

- Able to Communicate Thoughts and Ideas Using Written Information, etc.

- These prioritized gaps are aligned closely with the TUEE study results.

- We find we can cluster these gaps into four (4) logical categories:

- Cultivate the ability to make change happen

- Develop the abilities to Solve Problems

- Develop the abilities to communicate in many technical forms, e.g. assertive writing and analytical reading

- Cultivate an ability and a comfort level to collaborate and work effectively in teams 
- Comparing these gaps with how CETYS's new competency-based program is designed we are delighted to find that almost all of the Top 21 gaps are formally addressed.

- The comparison of gaps versus CETYS formal coverage of the material shows only three of the twenty-one highest overall industry gaps found in entry level engineers are not addressed in multiple classes.

- Understand how to make change happen

- Works well alone

- Emotional intelligence

- CETYS has launched efforts to determine how the three can be pedagogically addressed by intertwining new ideas and methods into the curriculum.

Per the recommendation of Cruz (Cruz, Mariana Leandro, Gillian N. Saunders-Smits \& Pim Groen, 2019) the CETYS study team conclude the study with a formal review with the Engineering Advisory Committee. Prioritized domains, competency gaps and CETYS Engineering course gaps were discussed and validated.

In conclusion, the two "simple" questions from the CETYS EAC have been formally addressed in a rigorous manner. Priorities in terms of domains of competencies have been prioritized and found to be consistent with external studies such as TUEE. Looking deeper into the specific competencies found lacking by entry level engineers at various companies in Baja, Mexico we find that CETYS Engineering formally addresses all but three of the top 21 gaps. Plans to address these three have now be developed because the College of Engineering knows where to focus its attention. The two questions from the EAC have been answered to the EAC's pleasure.

\section{References}

ABET (Accreditation Board for Engineering and Technology). (2014). Criteria for Accrediting Engineering Programs - 2015, Engineering Accreditation Commission, ABET, 415 North Charles Street, Baltimore, MD 21201.

Association of Professional Engineers and Geoscientists of British Columbia, CA. (APEGBC). (2012). Competency Assessment Guide. Retrieved from http://www.egbc.ca

Competency-based Education. (2015). Trend Perspective, Elsevier Publication.

Cruz, Mariana Leandro, Gillian, N., Saunders-Smits, \& Pim Groen. (2019). Evaluation of competency methods in engineering education: a systematic review. European Journal of Engineering Education. Taylor and Francis. https://doi.org/10.1080/03043797.2019.1671810

Dano, E. B. (2019). A Validated Systems Engineering Competency Methodology and Functional/Domain Competency Assessment Tool. 2019 International Symposium on Systems Engineering (ISSE), Edinburgh, United Kingdom, 2019, pp. 1-7. https://doi.org/10.1109/ISSE46696.2019.8984471

Davis, Denny, C., Richard Crain, Dale Calkins, Kenneth Gentili, \& Michael Trevisan. Categories and Levels for Defining Engineering Design Program Outcomes. Retrieved from https://peer.asee.org/categories_and_levels_for_defining_engineering_design_program_outomes

IET Skills and Demand in Industry - 2019 Survey, The Institute of Engineering and Technology, United Kingdom, 2019.

Jesick, Brent K., Natascha Trellinger Buswell, \& Qin Zhu. (2018). Global Engineering Competency: Assessment Tools and Training Strategies. Paper \#21663, American Society of Engineering Education.

Lang, James D, Susan Cruse, Francis D. McVey, \& John McMasters. (1999). Industry Expectations of New Engineers: A Survey to Assist Curriculum Designers. Journal for Engineering Education, 88(1). https://doi.org/10.1002/j.2168-9830.1999.tb00410.x

Mechatronics Competency Model. Competency Model Clearinghouse, Employment and Training Administration, U.S. Department of Labor. Retrieved from http://www.doleta.gov

OECD. (2015). Policy Priorities to Upgrade the Skills and Knowledge of Mexicans for Greater Productivity and Innovation. OECD Publishing, Paris.

OECD. (2016). Getting Skills Right: Assessing and Anticipating Changing Skills Needs. OECD Publishing, Paris. https://doi.org/10.1787/9789264252073-en 
Serna, Alejandra, Jose Luis Arcos Vega, Juan Jose Sevilla Garcia, \& Maria Amparo Oliveros Ruiz. (2018). Generic Competencies in the Education of Engineers: The Case of Engineering Program in a Public University in Mexico. Higher Education Studies, 8(1). https://doi.org/10.5539/hes.v8n1p58

The Engineer of Tomorrow. (2004). National Academy of Sciences. The National Academies Press, Washington, D.C. Transforming Undergraduate Education in Engineering (TUEE). (2013). Workshop Report, ASEE and NSF.

U. S. Department of Education. (2014). Competency-based Learning or Personalized Learning, U.S. Department of Education. Retrieved from www.ed.gov/oii-news/competency-based-learning-or-personalized-learning

Wall Street Journal. (2017). Exclusive Test Data: Many Colleges Fail to Improve Critical Thinking Skills. June 5, 2017.

Whitcomb, Clifford A., Corina White, Rabia Khan, Dana Grambow, Jose Velez, \& Jessica Delgado. (2017). The U.S. Department of Defense Systems Engineering Competency Model. INCOSE, 27(1), 214-228. https://doi.org/10.1002/j.2334-5837.2017.00355.x

\section{Copyrights}

Copyright for this article is retained by the author(s), with first publication rights granted to the journal.

This is an open-access article distributed under the terms and conditions of the Creative Commons Attribution license (http://creativecommons.org/licenses/by/4.0/). 